Shkodina I.

D.Sc. (Econ.), associate professor, professor at the International Business and Economic

Theory Dept.

V. N. KarazinKharkiv National University

Ukraine; e-mail:iryna.shkodina@karazin.u

Timoshenkov I.

D.Sc. (Econ.), associate professor, professor at the International Business and Economic

Theory Dept.

V. N. Karazin Kharkiv National University

Ukraine; e-mail: ivtimoshenkov@karazin.ua

Nashchekina $\boldsymbol{O}$.

Cand. Sc. (Phys. \& Math.), associate professor, associate professor at the Management and

Taxation Dept.

National technical university "Kharkov polytechnic institute"

Ukraine; e-mail:onashchekina@gmail.com

\title{
THE IMPACT OF FINANCIAL TECHNOLOGY ON THE TRANSFORMATION OF THE FINANCIAL SYSTEM
}

Based on our analysis of trends and threats associated with the use of financial technology, we conclude that its implementation increases the complexity of the institutional structure of the financial system. Certain institutional factors earlier regarded by scholars as anomalies that had either none or an insignificant effect on the development of the financial system are now emerging. These factors are becoming increasingly fundamental, and are in fact transforming the financial system. As the result, the established functional relations fail, while new institutions and new interdependences emerge, which leads to certain unforeseen destabilizing consequences.

The spontaneity of the process of systemic transformation determines human behavior, that is why it is not always possible to clearly anticipate the outcomes of such transformation.

Financial innovations are more difficult to regulate because there are no formal rules established for most of them, and they themselves are so novel that they fall outside the control of regulatory authorities. We believe that in order to prevent potentially adverse effects, it is necessary to strengthen the cooperation between government agencies and financial technology companies for the purpose of developing formal rules and procedures for ensuring the reliability and the security of the financial sector. It is important to work towards increasing the degree of trust and to establish a culture of innovation which would help the participants of financial markets adapt to the rapidly changing financial environment.

Keywords:financial market, financial technology, high-frequency trading, dark pools, blockchain, quantitative easing policy.

GEL classification: $\mathrm{G} 1, \mathrm{O} 16$

Formulas: 0; Fig.: 2; tabl.: 0; bibl.: 12

Шкодіна I. В.

д.е.н., доч., проф. кафедри міжнародного бізнесу та економічної теорії Харківського наџіонального університету імені В.Н. Каразіна Україна; e-mail: iryna.shkodina@karazin.ua

Тимошенков I. B.

д.е.н., доч., проф. кафедри міжнародного бізнесу та економічної теорії Харківського національного університету імені В.Н. Каразіна Україна; e-mail:ivtimoshenkov@karazin.ua 
Нащекіна О. М.

к.ф.-м.н., дои., дои. кафедри менеджменту та оподаткування Національного технічного університету «Харківський політехнічний інститут» Україна; e-mail:onashchekina@gmail.com

\section{ВПЛИВ ФІНАНСОВИХ ТЕХНОЛОГІЙ НА ТРАНСФОРМАЦІЮ ФІНАНСОВОЇ СИСТЕМИ}

Анотація. На основі аналізу тенденцій та загроз впровадження фінансових технологій, прийшли до висновку, що впровадження фінтеху стає причиною ускладнення інституційної структури фінансової системи, в результаті цього перестають діяти усталені функціональні зв'язки та з'являються нові інститути та взаємозалежності, які приводять до непередбачуваних дестабілізуючих негативних наслідків.Фінансові інновації складніше регулювати, оскільки більшість 3 них не мають формальних правил та настільки інноваційні, що не підпадають під контроль регулюючих структур. Вважаємо, що для попередження негативних наслідків застосування фінтеха, потрібно працювати над збільшенням рівня довіри,посилювати співпрацю державних органів 3 фінтехом для розробки формальних правил та процедур для забезпечення надійності та безпеки фінансового сектора.

Ключові слова: фінансовий ринок, фінансові технології, високочастотна торгівля, темні пули, блокчейн,політика кількісного пом'якшення.

Формул: 0; рис.: 2; табл.: 0; бібл.: 12

Шкодина И. В.

д.э.н., дои., проф. кафедры международного бизнеса и экономической теории Харьковского национального университета имени В.Н. Каразина Украина, е-mail:iryna.shkodina@karazin.ua

Тимоченков И. В. д.э.н., дои., проф. кафедры международного бизнеса и экономической теории Харьковского начионального университета имени В.Н. Каразина Украина; e-mail:ivtimoshenkov@karazin.ua Нащекина О. $\mathrm{H}$.

к.ф.-м.н., дои., дои. кафедрыменеджмента и налогообложения Национального технического университета «Харьковский политехнический институт» Украина; e-mail:onashchekina@gmail.com

\section{ВЛИЯНИЕ ФИНАНСОВЫХ ТЕХНОЛОГИЙ НА ТРАНСФОРМАЦИЮ ФИНАНСОВОЙ СИСТЕМЫ}

Аннотация. На основе анализа тенденций и угроз использования финансовых технологий, пришли к выводу, что их применение становится причиной усложнения институциональной структуры финансовой системы, в результате этого перестают действовать привычные функциональные связи и появляются новые институты и взаимозависимости, приводящие к непредсказуемым дестабилизирующим негативным последствиям. Современные финансовые инновации сложнее регулировать, поскольку большинство из них не имеют формальных правил и настолько инновационные, что не подпадают под контроль регулирующих структур. Считаем, что для предупреждения негативных последствий применения финтеха, необходимо работать над увеличением уровня доверия, усиливать сотрудничество государственных органов с финтех-компаниями для разработки формальных правил и процедур, обеспечивающих надежность и безопасность финансового сектора.

Ключевые слова: финансовый рынок, финансовые технологии, высокочастотная торговля, темные пулы, блокчейн, политикаколичественного смягчения.

Формул: 0; рис.: 2; табл.: 0; библ.: 12 
Introduction. The increasing global competition encourages the participants of the financial system to use financial technology (fintech). On the one hand, modern financial technology accelerates the functioning of the financial system, increases its profitability, and opens access to capital markets for new participants. On the other hand, the use of various financial innovations within the framework of fintech results in the creation of potentially unstable environment characterized by a high degree of uncertainty. The transformation of the financial system, including changes in its institutional design, characteristics, and the number of elements, as well as in the behavior of its participants takes place.

Since the influence of financial technology on the transformation of the financial system can lead to unpredictable consequences, it is of great importance to study the trends of those changes from both the scientific and the practical points of view.

Literature review. Recently the number of studies on the use of modern financial technology has significantly increased (Dong He, Ross B Leckow, Tommaso Mancini Griffoli, Mikari Kashima [1], Aditya Narain [2] and others) but currently, not enough attention has been paid to the impact of financial technology on the transformation of the financial system, dangers and threats associated with the implementation of fintech, the role and functions of regulatory institutions during the period of transformation.

The purpose of the article is to investigate the effect of modern financial technology on the transformation of the financial system based on the analysis of trends and threats related to the implementation of this technology.

The main results. Financial markets are early adopters of emerging cutting edge technologies because the profitability of transactions greatly depends on how fast information is transmitted and received. As the result of the advent and development of the Internet technology, trading in financial markets has moved into the virtual space, and since the late 90s, alternative trading systems (ATS) have been developing. From the formal legal standpoint, these systems cannot be regarded as exchanges because they do not perform securities listing functions, only offering the market participants an alternative, electronic, method of trading stocks. Besides, they have no obligation to provide information on the best prices to traders, and they do not establish rules that govern the traders' behavior, and neither are they self-regulating. It is because of the lack of the informational transparency that ATS are called "dark pools". Today, transactions in "dark pools" are carried out using algorithmic trading. In 2017, over 80 dark pools were registered in the United States alone. At the major European "darkpools" such as BATS (BXE), BlockMatch" BATS (CXE), Liquidnet, Nordic@Mid, POSIT, Six Swiss Exchange Liquidnet Service, SG CIB AlphaY, Turquoise Dark, UBS MTF, the monthly trade volume reach 80 billion euros [3].

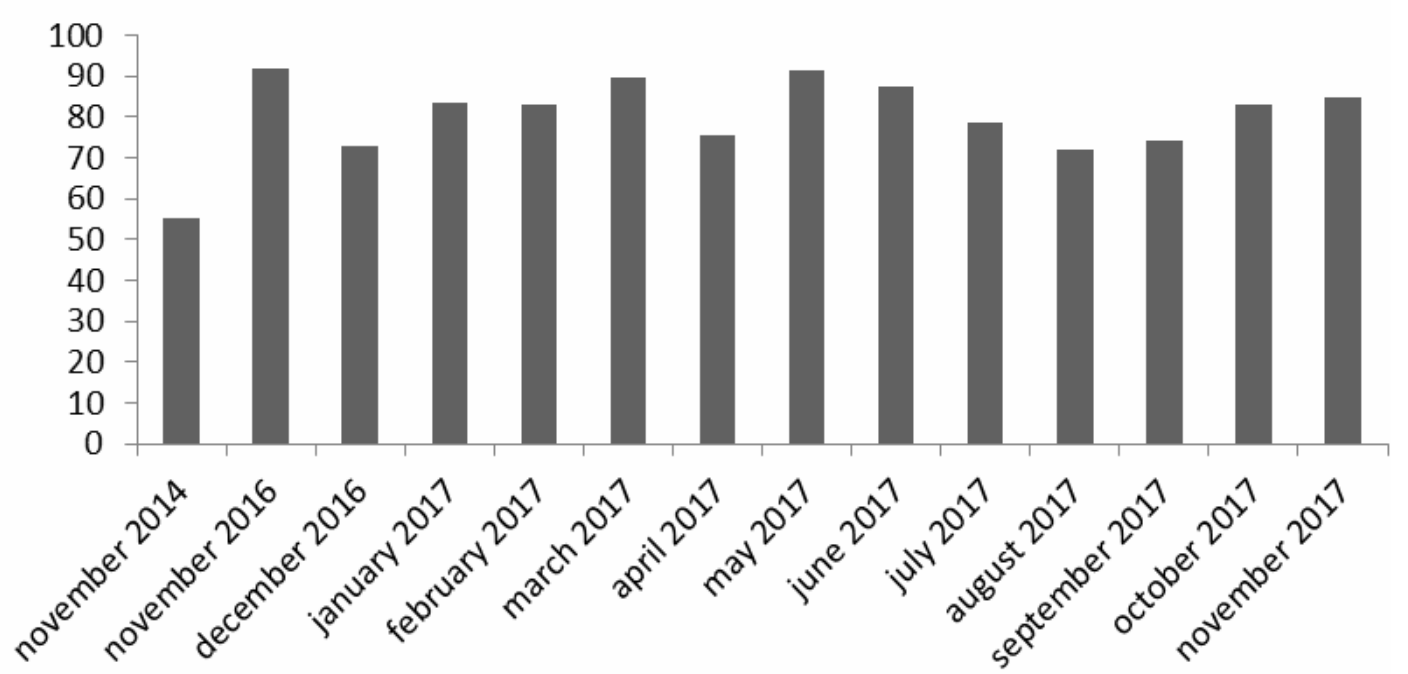

Fig. 1. Volume of trading in the European "dark pools", billion euros. Based on monthly reports by LiquidMetrix [3] 
The world largest commercial banks actively use their own "dark pools" for increasing their profits. Having trillions of dollars worth of deposits at their disposal, and operating in the absence of regulatory mechanisms for those quasi-exchanges, banks reduce the transparency of financial markets, alter the price-forming mechanisms, and increase the speculativeness and riskiness of the entire financial system. Because of the growing number of transactions in the "dark pools" and increasing difficulty of trading via the open and regulated stock exchanges, the financial markets today do not bring together the suppliers and the consumers of capital any longer. Nor do they transform savings into investments. They have been losing characteristics of traditional markets. They have been undergoing a transformation.

The structure of financial markets is also affected by high frequency trading (HFT), which is practiced today not only by large institutional players but also by private traders for receiving speculative profits. Technological advances that are expressed in milliseconds provide advantages to those investors who seek to benefit from the market volatility and quick transactions. This increases the probability of systemic malfunctions which can disrupt market operations. In our opinion, practically instant movements of huge volumes of liquid assets within the global trading networks may disrupt the well-established patterns of financial streams, the time for making rational decisions is drastically reduced, the cost of errors or technical failures becomes prohibitively high, which altogether leads to irreversible changes in the markets, and not necessarily positive ones.

Excess profits gained by investors in such markets have stimulated investments in innovations such as wireless networks, fiber-optic lines, and undersea cables linking global financial centers. Financial business has been investing heavily in developing artificial intelligence. Google and Schwab have been developing digital avatars and robo-advisory products which analyze all information relevant to the investor. The products developers anticipate that such avatars will not only follow the owners' commands but would also act on their own judgment when they understand what the owner wants. Bloomberg, Dow Jones and other financial information agencies sell subscriptions to news designed specifically for computers. Artificial intelligence is also used by different funds. The Cerebellum Capital hedge-fund, the Renaissance Technologies Fund, Chinese Baidu Inc., for instance, have launched applications forecasting the stock price dynamics. According to Luke Ellis, the CEO of Man Group Plc, in 25 years, up to $99 \%$ of investments will be managed with artificial intelligence [4].

However, on the other hand, excessive profitability of the financial sector has led to an increase in the number of the financial market participants, which, in turn, has reduced their profits. If in 2009, according to Tabb Group's estimates, the total revenue generated by HFT in securities in the USA amounted to US\$7.2 billion, in 2017, it dropped to US\$1 billion [5]. Today only large firms can compete in this market. This leads to financial firms consolidation and market monopolization. Thus, Virtu Financial has acquired KCG Holdings, Chicago DRW has acquired Chopper Trading and RGM Advisors. Leading financial companies such as Citadel LLC, Jump Trading LLC and Virtu Financial Inc, et al. have formed the Go West consortium that invests in the development of ultra high-speed financial transactions, and will offer investors the possibility of using its engines already in 2018.

The structure of financial markets is also changing under the influence of the blockchain technology. Blockchain technology is of interest to economists as well because it is based on a combination of cryptography and game theory. With the help of the blockchain technology, a decentralized electronic payment system is being developed. It is characterized by a high level of trustworthiness as a whole, although none of the system servers can be trusted individually. The innovativeness of blockchain lies in the possibility of managing a payment system in the absence of a central managing authority. A protocol sets the rules that all participants of the system (the socalled miners) abide by. Miners perform complex computations and follow the rules because they believe that others also comply with the protocol. Following the protocol maximizes expected profits of the participants. Thus, it is difficult to change the protocol because changes require a collective agreement on a new protocol. The technology will make it possible to simplify the 
technological processes, to abandon many current processes and elements of the information infrastructure, and thus to significantly reduce the cost and to increase the efficiency.

A positive network effect of this technology can hardly be expected before 2025, but the participants of the financial market are already exploring the possibilities of using it. According to the PwC's data, 30 percent of the banking sector participants are currently working toward the implementation of blockchain, and 90 percent of payment processing companies are planning to implement blockchain before 2020 [6]. The potential of this technology is also being examined in other sectors, including power industry, telecommunications, and pharmaceutical industry. The world's largest regulatory authorities are also involved. On the basis of blockchain technology, the German Central Bank (The Deutsche Bundesbank) together with the German stock exchange (the Deutsche Boerse) has been developing a functional prototype for the settlement of securities. This prototype will provide technical means for the settlement of securities in the "delivery against payment" mode, the transfer of digital securities without intermediaries, the payment of coupon income, and the redemption of securities. The analytical firm Transparency Market Research predicts that by 2024 the size of the global blockchain technology market will reach US $\$ 20$ billion, growing at an annual rate of 59 percent [7].

Today blockchain technology is most widely used in the cryptocurrency market. In 2017, the number of registered cryptocurrencies exceeded one thousand (there are 1097 cryptocurrencies listed on the website coinmarketcap.com). Almost 20 cryptocurrencies are among the most popular ones including Bitcoin, Ethereum, Ripple, Litecoin and others. The number of transactions in those currencies approaches half a million per day. The number of investors and companies that accept cryptocurrencies as a means of payment has been growing. It stimulates interest of operators of specialized cryptocurrency exchanges and drives up the prices of cryptocurrencies. The largest number, almost 90 percent of operations with cryptocurrency is carried out in Asia. In Japan, in accordance with the government regulation, cryptocurrencies are granted the official status of means of payment.

Due to the fact that investors have begun considering cryptocurrency a reliable financial asset that is worth investing into, the profitability of cryptocurrency has increased rapidly. The data of the CoinDesk's "State of Blockchain - Q2 2017" analytical report provide the evidence that the profitability of digital assets is many times higher than that of traditional assets (Fig.2). Today's enthusiasm among investors (by the way, mostly in poor and financially unstable countries), and an inconceivable increase in the prices of cryptocurrencies result from on the one hand, a new stage in the advances in information technology, and on the other hand, from the human desire of making a quick profit which makes investors ignore potential risks.

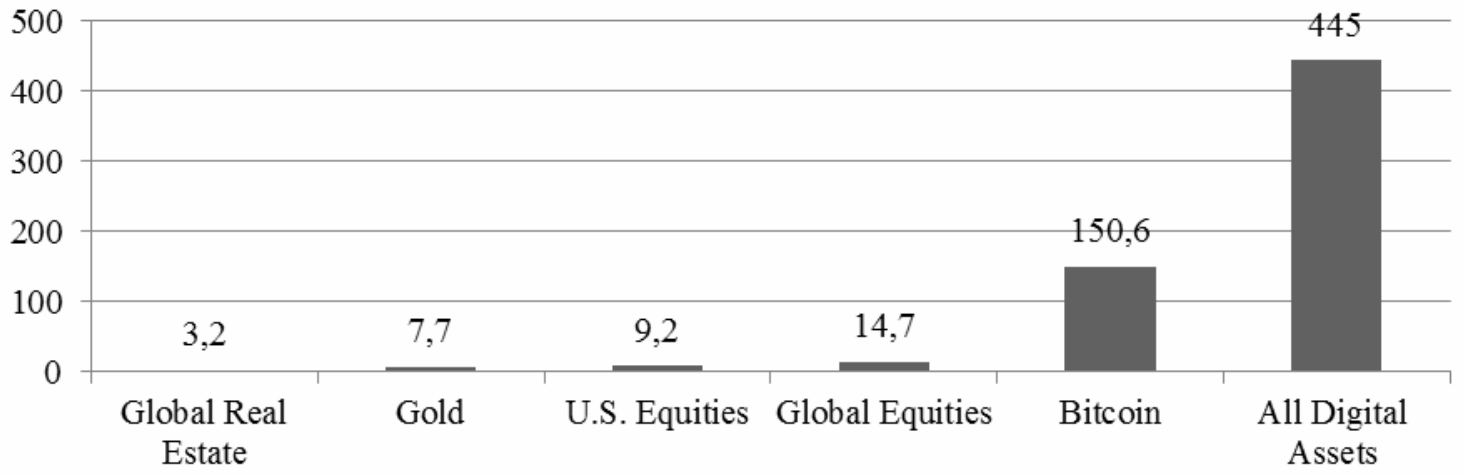

Fig.2 Profitability of digital vs. traditional assets in 2017, percent [8]

Some authors believe that cryptocurrencies have potential to enhance the financial system's stability. Anne Haubo Dyhrberg (2016) who studies the capabilities of bitcoin as a financial asset using the GARCH models concludes that it can be useful in risk management, and that it ideally suits risk averse investors. She places bitcoin as a financial instrument somewhere between gold and the U.S. dollar from the point of view of functions it performs - a medium of exchange and a store of value [9]. 
We support the viewpoint according to which an excessive profitability and volatility of the cryptocurrency market indicate the formation of a new financial bubble in that market. A Nobel Prize winner Robert Shiller holds the view that bitcoin is the best example of a speculative bubble in the modern world. Besides, taking into account that it is difficult to control the cryptocurrency market as compared to traditional financial ones, it is often used for money laundering, tax evasion, financial fraud and theft. According to the Nikkei and the Yomiuri Shimbun, that refer to the data provided by the National Police Agency (NPA), between January and July of 2017 cryptocurrencyrelated fraud resulted in losses of estimated US $\$ 710,848$ [10].

At present it is very difficult to predict what the future holds for cryptocurrency. However, analyzing the history of financial bubbles, one can be certain that the cryptocurrency market crash is inevitable. Prices that are formed as a result of cash inflow into the market are always unstable. If investors pay attention to fundamental economic indicators, it will bring down not only the cryptocurrency market but also the markets of all other financial assets. Any insignificant event may suffice to trigger the market crash. The history's greatest bubbles included the Dutch tulip mania bubble in 1637, the Internet (dot-com) bubble in the 90s, the tech bubble in 2000 and the United States housing bubble in 2007. At the same time, despite the irrational sizes of financial bubbles, bubbles may have positive consequences because, first, their formation is caused by the emergence of a new technologically promising phenomenon, e.g. railroads, the Internet, blockchain, etc. Thus bubbles spur investments in new industries. Second, crises help eliminate excessive speculation in the market and create an effective system of market regulation and market functioning. Although bubbles burst, we still use railroads and the Internet. That is why it is reasonable to introduce tight monitoring and control over new innovative financial instruments by government regulatory authorities because the market participants themselves change their behavior based on signals they receive, such as first of all, making or losing money.

By now, neither of the regulatory agencies has performed an in-depth, comprehensive analysis of threats related to the implementation of financial technology. The problem is that most studies are biased because they are funded by investment banks or other players that use innovative financial products. Besides, there are also technical barriers including the very large sizes, the sophistication and the cross-platform dispersion of statistical datasets.

The negative fact is that government regulators that ought to control the market and to prevent it from overheating, use it actively themselves in order to make profits. Quantitative easing (QE) policy adopted by the world's largest central banks led to the money supply growth. Super low interest rates did not contribute to an increase in the prices of goods and services but rather, combined with the processes of asset securitization and derivatives market expansion, have accelerated the growth in the prices of all risky financial assets to unprecedented levels. The global stock market has been growing at the highest rates in history against the backdrop of low volatility (in 2017, the VIX index was as low as 11, with the historical average value exceeding 20). One of the causes of such market behavior is the application of artificial intelligence which uses similar algorithms in trading. As the result, modern stock market turns into the act of trading for the sake of trading, where traders are not interested in the fundamental performance of companies. Such situation creates numerous systemic threats for the entire financial system.

As a consequence of QE, world central banks have accumulated over US \$20 trillion on their balance sheets. Considering the extremely low - sometimes even negative - returns on government securities, central banks have started investing their assets into the growing stock markets. For example, the Swiss National Bank (SNB) whose stocks are distributed among the cantons (45 percent), banks (15 percent), and private investors (40 percent), has invested approximately US $\$ 150$ billion in different companies' stocks. That constitutes 20 percent of the country's reserves.

Investing money in stocks of the likes of Apple (US\$3 billion), Alphabet (US\$2.2 billion), Microsoft (US\$2 billion), and other companies allowed the bank to increase its profitability. Between January and September of 2017, the SNB earned almost CHF34 billion, which exceeded the previous year's result by CHF24 billion. As a result, the profitability of its stocks increased. In 
2017, the stock price rose by 126 percent. A Japanese regulator now owns 75 percent of the national market of exchange-traded funds (ETF), the Italy's central bank has invested 6 percent of almost $€ 150$ billion of its reserves in stocks. A survey of central bank governors conducted by Invesco Ltd in 2017 showed that 80 percent of them were planning to increase their investments in the stock market [11]. In Janet Yellen's opinion, the United States Federal Reserve System, a.k.a. the Fed, may also start buying stocks to stimulate the economy which operates under the conditions of low interest rates and low inflation.

Thus, a change in the investment policy of the world's central banks that is radically changing their functions, has been taking place. This change is virtually turning them into hedgefunds aimed at making profits. Such developments pose a threat for the whole financial system. On the one hand, central banks have been increasing their investments in stocks, thereby pushing up the stock market indices and, as a result, widening the gap between the market securities prices and the securities prices based on companies' actual performance. That leads to the formation of bubbles. On the other hand, the declared policy of the interest rate normalization will have a negative effect the corporate securities market, and will reduce the profitability of stock portfolios held by the regulators themselves. It is difficult to predict what policy central banks will choose.

We have pointed out in a number of works [12] that the quantitative easing policy poses a threat to the global financial market. Today, such threat is high as never before. We believe that the next catalyst for other crisis phenomena will be a central banks' policy of extremely cheap money combined with negative interest rates. Such policy will lead to unpredictable consequences. The inactiveness of regulatory authorities that either failed to notice or did not want to recognize problems of the financial market, has already led to market crashes at various times. It is necessary to study the effect of financial technology on the scope and the speed of the financial system's transformation within a solid theoretical framework using the latest achievements in the field of economic theory.

Thus, the implementation of modern financial technology increases the complexity of the institutional structure of the financial system. New institutional factors that were regarded earlier by scholars as anomalies that have either none or a minimal effect on the financial system development have been emerging. Today, these factors are becoming increasingly fundamental, and are changing the financial system. As a result, some long-established functional relations are disappearing, while new institutions and interdependences are emerging, and together leading to unpredictable, destabilizing consequences. Unfortunately many of them are still being ignored until they become indisputable.

Conclusions.Financial market participants are actively implementing financial technology, which leads to changes in the institutional structure of the financial system. Those changes have both positive and negative effects. Actions that are rational from the standpoint of one financial market participant create systemic risks for other participants. Modern financial innovations are now more difficult to regulate because for most of them there are still no formal rules like in the case of the traditional financial institutions. They simply are so new that they fall outside the control of regulatory authorities.

To prevent adverse effects of financial innovations, it is necessary to strengthen the cooperation between government agencies and financial technology companies with a purpose of developing formal rules and procedures for ensuring the stability and the security of the financial sector. It is important to work towards increasing trust and to build an innovative culture which would help participants of financial market adjust to the rapidly changing financial environment.

Taking into account the fact that the process of the system's transformation takes place spontaneously, and in turn, defines human behavior, it is not always possible to clearly anticipate the consequences of such transformation. The transformation of the financial system is accelerated by various kinds of external shocks and "black swan" events. That is why it is necessary to intensify studies of the effect of financial technology on the transformational potential of financial markets if we want to be prepared to prevent and solve problems which will arise in the course of this transformation. 


\section{Література}

1. Fintech and Financial Services: Initial Considerations [Electronic resource] / Dong He et al. // Staff Discussion Notes. 2017. - 19 June. - 49 p. Available at: http://www.imf.org/en/publications/staff-discussion-notes/issues/2017/06/16/fintech-andfinancial-services-initial-considerations-44985.

2. Narain, A. Two Faces of Change [Electronic resource] / A. Narain // Finance \& Development. - 2016. - Vol. 53, № 3. Available at: http://www.imf.org/external/pubs/ft/fandd/2016/09/narain.htm.

3. LiquidMetrix Guide to European Dark Pools - December 2017 [Electronic resource]. - Available at: http://www.liquidmetrix.com/_LiquidMetrix/!Downloads/DarkPool/LiquidMetrix\%20Guide\%20to\%20European\%20Dark\%20Pools $\% 202017 \% 2012$.pdf.

4. Will the "black boxes" cause the next financial crisis? [Electronic resource]. - 2017. - 21 December. - Available at: $\mathrm{https}$ :/latest.13d.com/will-the-black-boxes-cause-the-next-financial-crisis-algorithmic-revolution-asset-management$\mathrm{d} 8827 \mathrm{c} 29 \mathrm{~b} 537$.

5. How high-frequency trading hit a speed bump [Electronic resource] // Financial Times. - Available at: https://www.ft.com/content/d81f96ea-d43c-11e7-a303-9060cb1e5f44.

6. Redrawing the lines: FinTech's growing influence on Financial Services [Electronic resource] : Global FinTech Report 2017. - Available at: https://www.pwc.com/jg/en/publications/pwc-global-fintech-report-17.3.17-final.pdf.

7. Blockchain Technology Market (Type - Public Blockchain, Private Blockchain, and Consortium Blockchain; Application Financial Services and Non-financial Sector) - Global Industry Analysis, Size, Share, Growth, Trends, and Forecast 2016-2024 [Electronic resource]. - Available at: https://www.transparencymarketresearch.com/blockchain-technology-market.html.

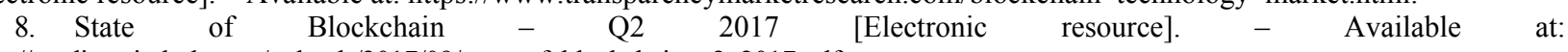
https://media.coindesk.com/uploads/2017/09/state_of_blockchain_q2_2017.pdf.

9. Dyhrberg, A. H. Bitcoin, Gold and the Dollar - A GARCH Volatility Analysis [Electronic resource] / A. H. Dyhrberg // Finance Research Letters. $\quad$ - 2016. $\quad$ - Vol. 16. - P. 85-92. Available at: https://www.sciencedirect.com/science/article/pii/S1544612315001038.

10. De, N. 33 Cases Cryptocurrency Fraud is on the rise in Japan [Electronic resource] / Nikhilesh De // Coindesk. - 2017. - 8 September. - Available at: https://www.coindesk.com/33-cases-cryptocurrency-fraud-is-on-the-rise-in-japan/

11. Invesco Ltd [Electronic resource]. - Available at: http://www.invesco.com/corporate.

12. Shkodina, I. Monetary policy as a factor of global financial market volatility increasing [Text] / I. Shkodina, Y. Yehorova, V. Yatsyna // Financial and credit activity: problems of theory and practice. - 2017. - № 1 (22). - P. 5-17.

Стаття надійшла до редакиіï 12.09.2017

(СШкодіна I. B.,

Тимошенков I. В., Нащекіна О. М.

\section{References}

1. He, D. (2017, June 19). Fintech and Financial Services: Initial Considerations. Staff Discussion Notes. Available at: http://www.imf.org/en/publications/staff-discussion-notes/issues/2017/06/16/fintech-and-financial-services-initial-considerations44985

2. Narain, A. (2016). Two Faces of Change. Finance \& Development, 53(3). Available at: http://www.imf.org/external/pubs/ft/fandd/2016/09/narain.htm

3. LiquidMetrix Guide to European Dark Pools. (2017, December). Available at: http://www.liquidmetrix.com/_LiquidMetrix/!Downloads/DarkPool/LiquidMetrix\%20Guide\%20to\%20European\%20Dark\%20Pools $\% 202017 \% 2012$.pdf

4. Will the "black boxes" cause the next financial crisis? (2017, December 21.). Available at: https://latest.13d.com/will-theblack-boxes-cause-the-next-financial-crisis-algorithmic-revolution-asset-management-d8827c29b537

5. How high-frequency trading hit a speed bump. Financial Times. Available at: https://www.ft.com/content/d81f96ea-d43c11e7-a303-9060cb1e5f44

6. Redrawing the lines: FinTech's growing influence on Financial Services: Global FinTech Report 2017. Available at: https://www.pwc.com/jg/en/publications/pwc-global-fintech-report-17.3.17-final.pdf

7. Blockchain Technology Market (Type - Public Blockchain, Private Blockchain, and Consortium Blockchain; ApplicationFinancial Services and Non-financial Sector). Global Industry Analysis, Size, Share, Growth, Trends, and Forecast $2016-2024$. Available at: https://www.transparencymarketresearch.com/blockchain-technology-market.html

8. State of Blockchain-Q2 2017. Available at: https://media.coindesk.com/uploads/2017/09/state of blockchain q2 2017.pdf

9. Dyhrberg, A. H. (2016). Bitcoin, Gold and the Dollar - A GARCH Volatility Analysis. Finance Research Letters, 16, 8592. Available at: https://www.sciencedirect.com/science/article/pii/S1544612315001038

10. De, N. (2017, September 8). 33 Cases Cryptocurrency Fraud is on the rise in Japan. Coindesk. Available at: https://www.coindesk.com/33-cases-cryptocurrency-fraud-is-on-the-rise-in-japan/

11. Invesco Ltd. Available at: http://www.invesco.com/corporate

12. Shkodina, I., Yehorova, Y., \& Yatsyna, Y. (2017). Monetary policy as a factor of global financial market volatility increasing. Financial and credit activity: problems of theory and practice, 1(22), 5-17.

Received 12.09.2017

(C)Shodina I., Timoshenkov I., Nashchekina O. 